\title{
Effects of exposure to acetochlor on the expression of thyroid hormone related genes in larval and adult rare minnow (Gobiocypris rarus)
}

\author{
Wei Li, Jinmiao Zha, Zhaoli Li, Lihua Yang, Zijian Wang* \\ State Key Laboratory of Environmental Aquatic Chemistry, Research Center for Eco-Environmental Sciences, Chinese Academy of Sciences, P.O. Box 2871, Beijing 100085, China
}

\section{A R T I C L E I N F O}

\section{Article history:}

Received 9 March 2009

Received in revised form 1 June 2009

Accepted 3 June 2009

\section{Keywords:}

Acetochlor

Deiodinases

Malic enzyme

Thyroid hormone disruption

Rare minnow (Gobiocypris rarus)

\begin{abstract}
A B S T R A C T
Acetochlor is a commonly used herbicide in agricultural environments, which can accelerate $T_{3}$-induced metamorphosis in amphibians. However, effects of acetochlor on the thyroid system in fish are still unclear at environmentally relevant concentrations. In this study, expression profiles of thyroid hormone receptor alpha $(t r \alpha)$, deiodinase ( $d 1$ and $d 2$ ), malic enzyme (me), and sodium iodide symporter (nis) genes were determined in larval and adult rare minnow (Gobiocypris rarus) after exposure to different levels of acetochlor $(20,200$, and $2000 \mathrm{ng} / \mathrm{l})$ for 21 days, respectively. Furthermore, plasma thyroid hormones (THs) levels in adults were evaluated simultaneously. The results showed that $d 1, d 2$, me, and nis mRNA levels were significantly down-regulated in the larvae. Similar expression changes of these genes in female brains were found. However, in adult livers, these gene expressions had no significantly effects, except the tr $\alpha$ mRNA level significantly up-regulated. These results indicated that exposure to acetochlor could result in tissue-specific alternative expression of TH-related genes in adults. Moreover, the expression of $d 2$ and $m e$ showed a positive correlation with plasma $\mathrm{T}_{4}$ levels in female brains. Therefore, larval development and adult brain of rare minnow could be affected by acetochlor at environmentally relevant concentrations.
\end{abstract}

(c) 2009 Elsevier B.V. All rights reserved.

\section{Introduction}

In recent years, a lot of endocrine disrupting chemicals (EDCs) have been released into the aquatic environment (Petrovic et al., 2004). Previous studies confirmed that some EDCs could cause disturbance of thyroid hormone homeostasis, hypothyroidism, and thyroid gland abnormalities in fish (Arukwe and Jenssen, 2005). As a significant portion of EDCs, several pesticides are potential endocrine disrupters, which alter the normal functioning of the endocrine system (Charlier and Plomteux, 2002). The use of pesticides on agricultural land may result in contamination of adjacent surface waters and thus pose a potential risk to a range of aquatic organisms such as fish (Guo et al., 2008). However, studies on disruption of the thyroid system in fish are limited (van der Ven et al., 2006).

Acetochlor (2-chloro-N-(ethoxymethyl)-N-(2-ethyl-6-methylphenyl)-acetamide) is a common herbicide all over the world (Lengyel and Foldenyi, 2003), which has been widely used in China (Ye, 2003). Previous studies have demonstrated the presence of acetochlor in surface water (Hladik et al., 2008), soil (Chao et al., 2007), and sediment (Xue et al., 2005). Measurable concentrations of acetochlor ranged from 0.05 to $2.5 \mu \mathrm{g} / \mathrm{l}$ in surface water (Boyd, 2000;

\footnotetext{
* Corresponding author. Tel.: +86 10 62849140; fax: +8610 62929140 .

E-mail address: wangzj@rcees.ac.cn (Z. Wang).
}

Hladik et al., 2008; Kolpin et al., 1996). Acetochlor has been classified by the US EPA as a B-2 carcinogen (U.S. EPA, 1994). Furthermore, acetochlor can accelerate $\mathrm{T}_{3}$-dependent metamorphosis in amphibians (Cheek et al., 1999; Crump et al., 2002; Helbing et al., 2006). However, the effects of acetochlor alone on the thyroid system of fish are unclear.

The thyroid hormones (THs) triiodothyronine $\left(\mathrm{T}_{3}\right)$ and thyroxine $\left(\mathrm{T}_{4}\right)$ have a wide range of biological effects in physiological processes of vertebrates (Power et al., 2001). In fish, THs have been implicated as being important regulators in differentiation, growth, metabolism, and salinity adaptation (Crane et al., 2004; Orozco et al., 2002). The effects of exposure to EDCs may be multiple targets with the complex regulatory network of thyroid hormone metabolism and action: TH receptors (TR), mediating gene regulation in response to $\mathrm{T}_{3}$ (Marchand et al., 2001); deiodinase enzyme (D1 and D2), outer ring deiodination of $\mathrm{T}_{4}$ to the biologically active $\mathrm{T}_{3}$ (Orozco and Valverde, 2005); malic enzyme (ME), having a central role providing NADPH for fatty acid biosynthesis lipid metabolism and being a wellcharacterised endpoint of THs action (Rosebrough et al., 2006); and the sodium iodide symporter (NIS), an integral plasma membrane glycoprotein of thyroid hormone synthesis (Dohan et al., 2003). Previous studies indicated that the gene expressions of $\mathrm{TH}$ receptors and deiodinases were sensitive molecular biomarkers for thyroid disruption in fish exposed to environmental contaminants (Picard-Aitken et al., 2007; Scholz and Mayer, 2008). However, little 
is known about the me and nis genes as potential biomarkers in fish.

Rare minnow (Gobiocypris rarus) is considered to be an appropriate species for the assessment of endocrine disrupting chemicals due to its small size, ease of culture, short life cycle and prolific egg production with high fertilization and hatching rates (Zha et al., 2007). Rare minnow is an ideal model fish in the laboratory. We have been focused on changes of the hypothalamic-pituitary-gonad (HPG) axis in Chinese rare minnow by environment pollutants (Zha et al., 2008; Zhang et al., 2008). However, the potential disruption of hypothalamic-pituitary-thyroid (HPT) axis is largely unknown.

With the advances in molecular approaches, the application of toxicogenomics could be a powerful tool for evaluating the effects and discovering molecular mechanisms underlying toxic response (Nie et al., 2006). Therefore, in this study, we suppose that the expressions of tr $\alpha, d 1, d 2, m e$, and nis genes can be potential biomarkers to study on disruption of the thyroid system. Our studies aimed at investigating the effects of environmentally relevant concentrations of acetochlor on plasma THs levels and the expression of THs related genes of larvae and adult rare minnow, and discussing the possible molecular mechanisms underlying toxic response.

\section{Materials and methods}

\subsection{Chemicals}

Acetochlor was purchased from Sigma-Aldrich Chemical Co. (USA). Stock solution of acetochlor was prepared by dilution in dimethylsulfoxide (DMSO) (Absolute grade), which was purchased from Tedia Company Inc. (Fairfield, OH, USA). To obtain the final concentration for exposure, the appropriate amount of the stock solution was added to the aquarium water via a combination of polytetrafluorethylene (PFTE) and isoversinic tubes (Abimed, Langenfeld, Germany). A vehicle treatment containing a combination of DMSO served as a control. The ratio of vehicle to water was $1: 100,000$ (vol/vol).

\subsection{Test fish and culture conditions}

The brood stock of rare minnow was raised in a flowthrough system with dechlorinated tap water ( $\mathrm{pH}$ 7.2-7.6; hardness 44.0-61.0 $\left.\mathrm{mg} \mathrm{CaCO}_{3} / \mathrm{l}\right)$ at a constant temperature $\left(25 \pm 1^{\circ} \mathrm{C}\right)$ with a photoperiod of 16:8 h (light:dark) and has been used for testing chemicals in our laboratory for more than 6 years (Zha et al., 2007). Fish were fed a commercial food pellet (Trea, Germany) at a rate of $0.1 \%$ body weight per day and newly hatched brine shrimp (Artemia nauplii) two times daily.

\subsection{Exposure and experimental design}

Experiment 1: Newly hatched larvae $(n=120)$ were the offspring from the same pair of brood stock and were randomly divided into four groups. Larvae were exposed to various concentrations (control, 20, 200, and $2000 \mathrm{ng} / \mathrm{l}$; nominal concentrations) of acetochlor for 21 days. Larvae were under flow-through conditions at $25 \pm 1{ }^{\circ} \mathrm{C}$ with a photoperiod of $16: 8 \mathrm{~h}$ (light:dark). After 3 days posthatching, larvae were fed newly hatched brine shrimp (A. nauplii) two times daily. Waste and residue were removed daily while the test equipment and chambers were cleaned once a week. After 21 days exposure, larvae were sacrificed and stored at $-80^{\circ} \mathrm{C}$ until RNA extractions.

Experiment 2: Healthy adult rare minnows $(n=120), 5$ months old and the offspring from the same pair of brood stock, were randomly divided into four groups. Fish were exposed under flowthrough conditions to various concentrations (control, 20, 200, and
$2000 \mathrm{ng} / \mathrm{l}$; nominal concentrations) of acetochlor. Fish in each group were sacrificed after 21 days exposure. Blood was collected from each fish in a heparinized microcapillary tube. The samples were immediately centrifuged $\left(8000 \times \mathrm{g}, 10 \mathrm{~min}, 4^{\circ} \mathrm{C}\right)$, and the plasma were kept frozen at $-80^{\circ} \mathrm{C}$ until use. In addition, the livers and brains were excised, flash-frozen in liquid nitrogen and stored at $-80^{\circ} \mathrm{C}$ until analysis.

\subsection{Plasma THs measurement}

Plasma $\mathrm{T}_{4}$ and $\mathrm{T}_{3}$ were measured using commercial radioimmunoassay kits purchased from Beijing North Institute of Biotechnology, China, using sample volumes of $50 \mu$ l for $\mathrm{T}_{4}$ and $\mathrm{T}_{3}$. The RIAs for $T_{4}$ and $T_{3}$ were validated for use with rare minnow samples by demonstrating parallelism between a series of diluted and spiked plasma samples in relation to the standard curve. The inter-assay coefficients of variation for both $\mathrm{T}_{4}$ and $\mathrm{T}_{3}$ were less than $5 \%$ and intra-assay coefficients of variation less than $10 \%$. Cross reactivity between $\mathrm{T}_{4}$ and $\mathrm{T}_{3}$ antibodies was less than $0.5 \%$. Assay sensitivities were 3 and $0.25 \mathrm{ng} / \mathrm{ml}^{\text {for }} \mathrm{T}_{4}$ and $\mathrm{T}_{3}$, respectively.

\subsection{Real-time PCR}

Total RNA was isolated from whole larvae and the livers and brains of adults using Trizol reagent (Life Technology). Then RNA samples were dissolved in ribonuclease-free water and stored at $-80^{\circ} \mathrm{C}$ until the process of reverse-transcriptase polymerase chain reaction.

The reverse transcription reaction mixtures containing $10 \mu \mathrm{l}$ of total RNA, $2 \mu \mathrm{l}(0.05 \mu \mathrm{g} / \mu \mathrm{l})$ of $\operatorname{Oligo}(\mathrm{dT})_{15}$, and diethyl pyrocarbonate-treated water (a total volume of $12 \mu \mathrm{l}$ ), were heated to $70^{\circ} \mathrm{C}$ for $5 \mathrm{~min}$ and quickly chilled on ice. After cooling, $50 \mathrm{mM}$ Tris- $\mathrm{HCl}$ buffer ( $\mathrm{pH} 8.3$ ), $75 \mathrm{mM} \mathrm{KCl,} 10 \mathrm{mM}$ dithiothreitol, $3 \mathrm{mM}$ $\mathrm{MgCl}_{2}, 2 \mathrm{mM}$ deoxynucleotide triphosphate (10 mM each), 40 units of RNAasin (RNAase inhibitor; Promega), and $200 \mathrm{U}$ of Moloney Murine Leukemia Virus Reverse Transcriptase (Promega) were added to a total volume of $25 \mu \mathrm{l}$ and incubated for $1 \mathrm{~h}$ at $37^{\circ} \mathrm{C}$. Thereafter, the reaction mixture was heated to $70^{\circ} \mathrm{C}$ for $10 \mathrm{~min}$ to inactivate the reverse transcription.

Real-time PCR was performed in a MX3005P real-time quantitative polymerase chain reaction system (Stratagene, USA) in a total volume of $25 \mu \mathrm{l}$, consisting of the Brilliant II SYBR Green QPCR master mix, $300 \mathrm{nM}$ forward primer and $300 \mathrm{nM}$ reverse primer. The forward and reverse primers used and PCR products were listed in Table 1 . The thermal cycle parameters used were: $10 \mathrm{~min}$ at $95^{\circ} \mathrm{C}, 40$ cycles of $30 \mathrm{~s}$ at $95^{\circ} \mathrm{C}, 1 \mathrm{~min} 57^{\circ} \mathrm{C}$ and $30 \mathrm{~s}$ at $72^{\circ} \mathrm{C}$. All the samples were analyzed in triplicate and the mean value of these triplicate measurements were used for calculations of mRNA expressions. Results were analyzed according to delta-delta $\mathrm{Ct}$ method. The tr $\alpha$, $d 1, d 2$, me, and nis mRNA expressions were normalized for $\beta$-actin mRNA expression. Dissociation curve analysis was performed for each gene to check the amplification of untargeted fragments. Only one peak was observed for each amplification, indicative for the amplification of the target gene only. Gene expression data are presented as change relative to control animals within the same treatment period.

\subsection{Statistics}

All statistical analyses were performed with the SPSS (version 13.0; USA). All quantitative data are expressed as the mean \pm S.E. of the mean (S.E.M.). Statistical analysis of the data was performed using analysis of variance, followed by Bonferroni's Multiple Comparison Test. A probability of $p<0.05$ was considered statistically significant. 
Table 1

Primers used for the quantification of the mRNA expression by real-time PCR.

\begin{tabular}{|c|c|c|c|}
\hline Gene & Sequence $\left(5^{\prime} \rightarrow 3^{\prime}\right)$ & Product size (bp) & Genbank accession no. \\
\hline$\beta$-actin & $\begin{array}{l}\text { F: CAGGGCGTGATGGTGGGGAT } \\
\text { R: GGTTGGCTTTGGGGTTGAG }\end{array}$ & 226 & DQ539421 \\
\hline $\operatorname{tr\alpha }$ & $\begin{array}{l}\text { F: ATGGACTTGGTGCTGGACGA } \\
\text { R: ATTGGTGTGGCGATGAGCCT }\end{array}$ & 173 & EU725804 \\
\hline$d 1$ & $\begin{array}{l}\text { F: GTTCAAACAGCTTGTCAAGGACTTC } \\
\text { R: AGCAAGCCTCTCCTCCAAGTT }\end{array}$ & 142 & EU725801 \\
\hline$d 2$ & $\begin{array}{l}\text { F: GGATGAGTCGGAAAGGTGAA } \\
\text { R: CCACACTAAGCAAGCCCATT }\end{array}$ & 88 & EU725803 \\
\hline$t$ tr & $\begin{array}{l}\text { F: TGTATCGGGTGGAGTTTGACA } \\
\text { R: GAAGAAGAGCCAGAGTGTAA }\end{array}$ & 130 & EU725802 \\
\hline nis & $\begin{array}{l}\text { F: TGGGTGTAGTGAACGGTCCA } \\
\text { R: CGGTTTATTTGTGGCGGGAAC }\end{array}$ & 71 & FJ624477 \\
\hline me & $\begin{array}{l}\text { F: TGTCAAGGCTGTGGTGGTGA } \\
\text { R: AGGCAACTCTCAGGTCGGAT }\end{array}$ & 133 & EU744545 \\
\hline
\end{tabular}

Table 2

Growth, gonadosomatic index (GSI) and hepatosomatic somatic index (HSI) of rare minnow at the end of acetochlor exposure.

\begin{tabular}{|c|c|c|c|c|c|c|c|}
\hline \multirow[t]{2}{*}{ Concn. (ng/l) } & \multicolumn{3}{|c|}{ Body length (mm) } & \multicolumn{2}{|l|}{ GSI (\%) } & \multicolumn{2}{|l|}{ HSI (\%) } \\
\hline & Larvae & Males & Females & Males & Females & Males & Females \\
\hline Control & $12.5 \pm 0.5$ & $46.1 \pm 2.0$ & $47.9 \pm 2.2$ & $4.1 \pm 1.0$ & $17.7 \pm 2.6$ & $1.0 \pm 0.5$ & $1.9 \pm 0.6$ \\
\hline 20 & $11.5 \pm 0.4$ & $45.9 \pm 2.0$ & $46.4 \pm 2.0$ & $4.4 \pm 0.7$ & $15.5 \pm 3.4$ & $1.2 \pm 1.0$ & $1.9 \pm 1.0$ \\
\hline 200 & $11.1 \pm 0.5$ & $43.6 \pm 2.1^{a}$ & $45.7 \pm 3.8$ & $3.2 \pm 1.1^{\mathrm{a}}$ & $17.2 \pm 3.4$ & $1.4 \pm 0.6$ & $1.5 \pm 0.3$ \\
\hline 2000 & $11.9 \pm 0.5$ & $43.0 \pm 2.3^{a}$ & $46.1 \pm 1.4$ & $3.8 \pm 0.8$ & $19.6 \pm 4.5$ & $1.3 \pm 0.3$ & $2.1 \pm 0.5$ \\
\hline
\end{tabular}

Data expressed as mean \pm S.E. of each treatment (larvae, $n=30$; males or females, $n=15$ ).

a Statistically significant difference from the control $(p<0.05)$.

\section{Results}

\subsection{The exposure experiment in larvae}

\subsubsection{Mortality and growth}

No mortality was observed in treatment and control groups during the exposure period. At the end of acetochlor exposure, there was no significant difference in growth of larvae (Table 2 ).

\subsubsection{Quantitation of tro, d1, d2, me, and nis mRNA at the larval} stage

The mRNA expressions of $t r \alpha, d 1, d 2, m e$, and nis in whole larvae were determined by real-time PCR after the 21-day exposure to acetochlor (Fig. 1). The tr $\alpha$ mRNA levels were significantly increased at $20 \mathrm{ng} / \mathrm{l}(p<0.05)$, but significantly decreased at $200 \mathrm{ng} / \mathrm{l}$. The $d 1$, $d 2$, and nis mRNA levels were significantly down-regulated at 200 and $2000 \mathrm{ng} / \mathrm{l}$ compared with the control $(p<0.05)$. Moreover, the expression of me mRNA was significantly down-regulated only at $2000 \mathrm{ng} / \mathrm{l}(p<0.05)$.

\subsection{The exposure experiments in adults}

\subsubsection{Mortality and growth}

No mortality was observed in treatment and control groups during the exposure period. The body length of males treated at 200 and $2000 \mathrm{ng} / \mathrm{l}$ were significantly lower than those in controls $(p<0.05)$. In contrast, no significant change in body length was observed in females. The GSI of males was significantly affected at $200 \mathrm{ng} / \mathrm{l}(p<0.05)$. However, the HSI of females and males at all treatments did not show statistically differences compared to the controls (Table 2).

\subsubsection{Plasma thyroid hormone levels}

At the end of exposure, plasma $\mathrm{T}_{4}$ levels at 200 and $2000 \mathrm{ng} / \mathrm{l}$ were significantly lower than those at the controls $(p<0.05)$
(Table 3 ). The plasma $\mathrm{T}_{3}$ levels were significantly decreased at the concentration of $200 \mathrm{ng} / \mathrm{l}(p<0.05)$, whereas no significant differences in plasma $\mathrm{T}_{3}$ were observed among other treatment and control groups.

\subsubsection{Quantitation of tro, $d 1, d 2$, me, and nis mRNA in livers and} brains of adults

In the liver of rare minnow, only tr $\alpha$ mRNA levels were significantly increased in all treatment groups for both males and females $(p<0.05)$ (Fig. 2), whereas no significant effects for expression of $d 1$, $d 2$, and me mRNA at the end of the exposure $(p<0.05)$.

In the brain of rare minnow, the $11 \mathrm{mRNA}$ could not be expressed at high levels, whereas the nis mRNA expressed at the highest level (data not shown). For males, the tr $\alpha$ mRNA levels were significantly increased in brains at $20 \mathrm{ng} / \mathrm{l}$, whereas significant decreases were observed at 200 and $2000 \mathrm{ng} / \mathrm{l}$. The $d 2 \mathrm{mRNA}$ levels were significantly down-regulated at all treatments. No significant effects were observed in nis and me mRNA levels compared with the control. For females, the tr $\alpha$ mRNA levels were significantly increased in brains at $200 \mathrm{ng} / \mathrm{l}$, whereas a significant decrease was observed at $2000 \mathrm{ng} / \mathrm{l}$. The expression of $d 2$ and me were significantly downregulated at 200 and $2000 \mathrm{ng} / \mathrm{l}(p<0.01)$. The expression of nis were significantly down-regulated at all treatments. Moreover, the

Table 3

Plasma concentrations of $\mathrm{T}_{4}$ and $\mathrm{T}_{3}$ after acetochlor exposure in males and females.

\begin{tabular}{llcccc}
\hline Concn. $(\mathrm{ng} / \mathrm{l})$ & \multicolumn{2}{l}{$\mathrm{T}_{4}(\mathrm{ng} / \mathrm{ml})$} & & \multicolumn{2}{l}{$\mathrm{T}_{3}(\mathrm{ng} / \mathrm{ml})$} \\
\cline { 2 - 3 } & Males & Females & & Males & Females \\
\hline Control & $80.1 \pm 4.3$ & $101.9 \pm 6.3$ & & $5.2 \pm 0.6$ & $5.8 \pm 0.7$ \\
20 & $74.8 \pm 5.2$ & $89.9 \pm 6.4$ & & $4.5 \pm 0.5$ & $5.3 \pm 0.5$ \\
200 & $37.4 \pm 6.4^{\mathrm{a}}$ & $66.5 \pm 5.8^{\mathrm{a}}$ & & $2.3 \pm 0.5^{\mathrm{a}}$ & $3.2 \pm 0.4^{\mathrm{a}}$ \\
2000 & $21.8 \pm 5.3^{\mathrm{a}}$ & $69.8 \pm 7.4^{\mathrm{a}}$ & & $4.9 \pm 0.7$ & $4.6 \pm 0.6$
\end{tabular}

Data expressed as mean \pm S.E. of each treatment $(n=5)$.

a Statistically significant difference from the control $(p<0.05)$. 

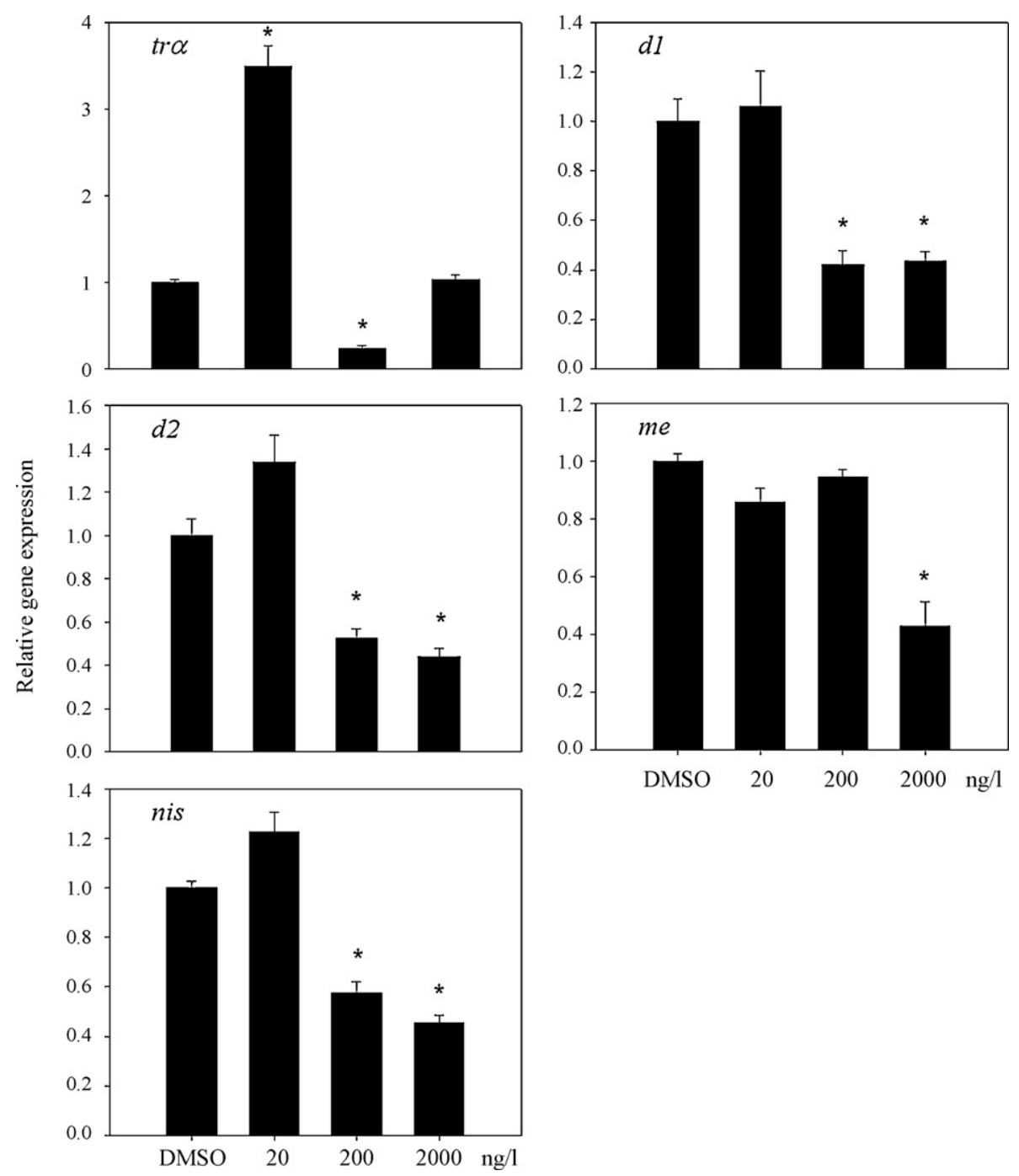

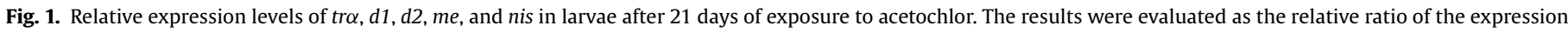
level of each mRNA to that of $\beta$-actin. Data expressed as mean \pm S.E. of each treatment $(n=5) .{ }^{*} p<0.05$, relative to control.

expression of $d 2$ and $m e$ in brains showed a positive correlation with plasma $\mathrm{T}_{4}$ levels in females $(r=0.991, p=0.009 ; r=0.996, p=0.007)$. The changes of tr $\alpha$ mRNA levels in larvae showed a significant positive correlation with those in brains of females $(r=0.976, p=0.024)$.

\section{Discussion}

Synthetic organic pesticides have been detected frequently in ground water, surface water, aquatic biota and sediment, and atmosphere in decades (Barbash et al., 2001). As a common pre-emergent herbicide all over the world, measurable concentrations of acetochlor can accelerate $\mathrm{T}_{3}$-induced metamorphosis in amphibians. In this study, effects of environmentally relevant concentrations of acetochlor on the expression of tr $\alpha, d 1, d 2, m e$, and nis genes were investigated in larvae and adults rare minnow under laboratory conditions.

Our studies found that there was no significant difference in growth of larvae, whereas the body length of males treated at 200 and $2000 \mathrm{ng} / \mathrm{l}$ were significantly lower than those in controls after 21-day exposure to acetochlor (Table 2). Previous studies observed that $10 \mathrm{nM}(2.7 \mu \mathrm{g} / \mathrm{l})$ acetochlor accelerated $\mathrm{T}_{3}$-induced forelimb emergence, but acetochlor alone did not alter metamorphosis of Rana pipiens after 7-day exposure (Cheek et al., 1999). Furthermore, no differences in body area of Xenopus Laevis were observed after
$72 \mathrm{~h}$ of exposure to $10 \mathrm{nM}$ acetochlor (Crump et al., 2002). These results indicate that acetochlor alone may not affect the development of early life stage of aquatic organisms at environmentally relevant concentrations.

In this study, treatment with acetochlor at 200 and $2000 \mathrm{ng} / \mathrm{l} \mathrm{sig-}$ nificantly decreased plasma $\mathrm{T}_{4}$ levels in adult rare minnow, as well as decreased plasma $\mathrm{T}_{3}$ levels at $200 \mathrm{ng} / \mathrm{l}$ (Table 3). Acetochlor can increase glucuronidation of THs and decrease THs levels in rodents (Hurley, 1998). In addition, alachlor could significantly decrease circulating levels of $\mathrm{T}_{4}$ after 7 days and return to control levels after 60 days in male Long-Evans rats at the concentration of $126 \mathrm{mg} / \mathrm{kg}$ (body wt/day) (Wilson et al., 1996). Therefore, the present data suggested that acetochlor can decrease circulating THs levels of fish at environmentally relevant concentrations.

In present study, the transcription of tr $\alpha$ was up-regulated in livers of adults, whereas a non-linear dose-response relationship was observed at different doses of acetochlor in the transcription of tr $\alpha$ of larvae and brains of adults. The changes of tr $\alpha$ mRNA levels in larvae showed a significant positive correlation with what observed in brains of females. As was previously reported, the transcript levels of $\operatorname{tr} \alpha$ and $\operatorname{tr} \beta$ were increased in tail and brain of Rana catesbeiana tadpole after short-term exposure to $10 \mathrm{nM}$ acetochlor (Helbing et al., 2006; Veldhoen and Helbing, 2001). However, the expression of both $\operatorname{tr} \alpha$ and $\operatorname{tr} \beta$ mRNA transcripts was not affected by 

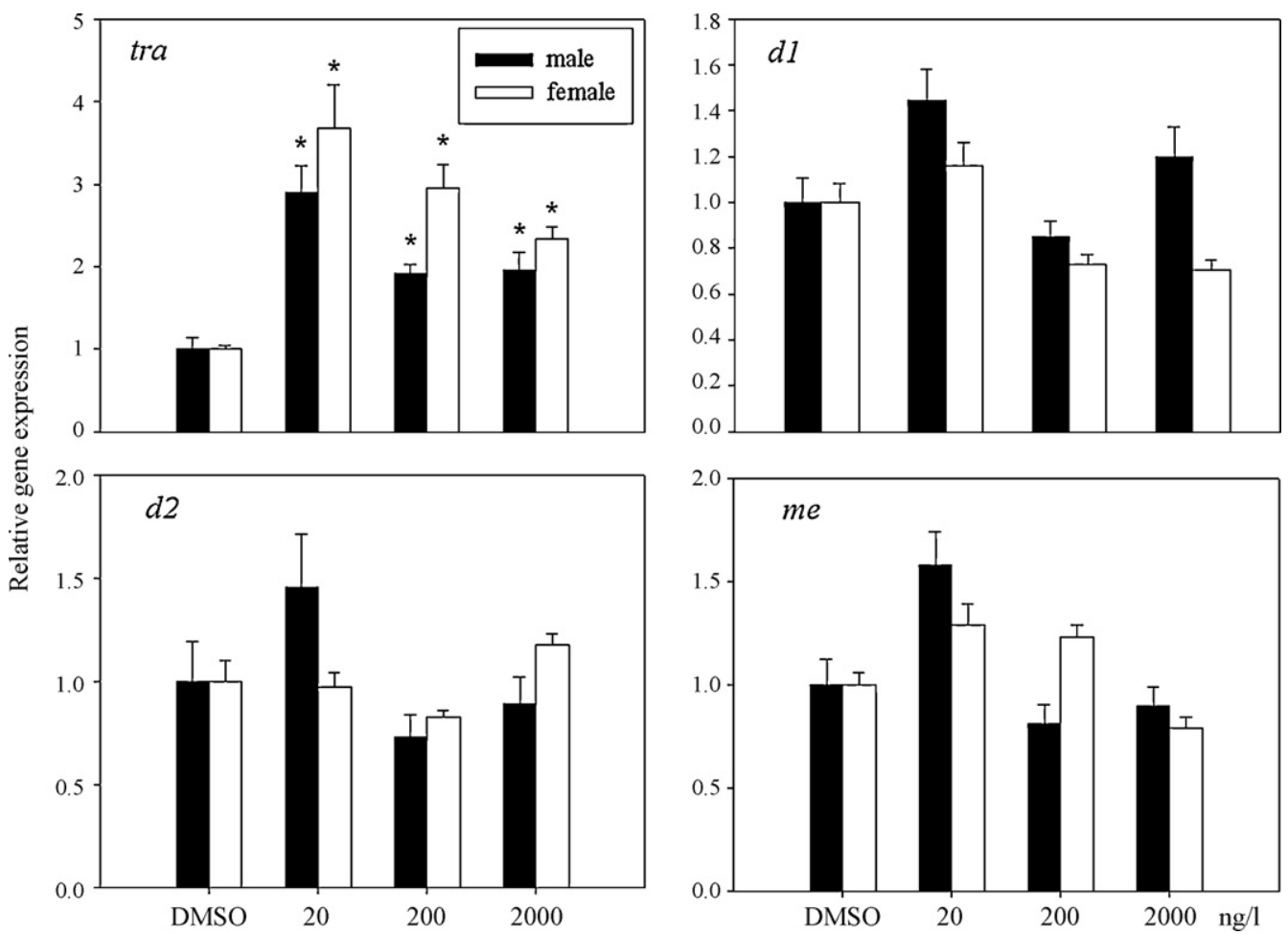

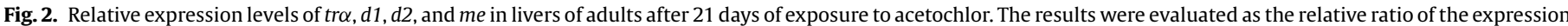
level of each mRNA to that of $\beta$-actin. Data expressed as mean \pm S.E. of each treatment (males or females, $n=5$ ). ${ }^{*} p<0.05$, relative to control.

$48 \mathrm{~h}$ of acetochlor treatment in X. laevis tadpole tail tissue (Crump et al., 2002). One possible explanation for the transcription of tra levels could be that feedback systems attempt to respond to a disturbance of HPT axis homeostasis. Therefore, further studies are needed to discover the change of THs receptors transcription levels in a long-term exposure experiment.

Iodothyronine deiodinases are important regulators of circulating and intracellular THs levels in fish (Orozco and Valverde, 2005). In present study, the $d 1$ and $d 2$ mRNA levels were not significantly changed in the livers of adults (Fig. 2). As was previously reported, the hormone-dependent increase of $d 3$ expression was slightly attenuated with no effect on the expression of $d 2$ mRNA by acetochlor $(10 \mathrm{nM})$ treatment in tail tissue of $X$. laevis tadpoles (Crump et al., 2002). These results might mean that $T_{3}$ homeostasis is not a compensatory mechanism by increasing D2 expression. D3 is of emerging significance for it inactivates both $T_{4}$ and $T_{3}$ by inner-ring deiodination (Orozco and Valverde, 2005). Although we were unable to measure the change of $d 3$ mRNA levels in this study, it is more likely that a reduction in the rate of $\mathrm{T}_{3}$ inactivation may be manifested as a regulation of HPT axis in fish if the mechanisms in X. laevis could be applied to fish. In the current study, the $d 2$ mRNA levels were significantly down-regulated in larvae and brains of adults. Moreover, the profiles of $d 2$ mRNA levels in brains showed a positive correlation with plasma $\mathrm{T}_{4}$ levels in females. In fish, hyperthyroidism suppresses D1 and D2 activities and expressions of their mRNA while hypothyroidism increases them (Orozco and Valverde, 2005; Van der Geyten et al., 2005). However, the effects of acetochlor treatment on $d 2$ mRNA and plasma THs levels in brains are contrary to what would be expected. It is more likely that the expression of $d 2$ mRNA may be a direct gene response in the brain, similar to the $d 2$ expression induced by $\mathrm{T}_{3}$ treatment in the tadpole brain (Hogan et al., 2007). Similar results were also obtained in chick brains (Reyns et al., 2003), where $\mathrm{D} 2$ showed a positive correlation with plasma $\mathrm{T}_{4}$ levels. Therefore, these results indicated that exposure to acetochlor at environmentally relevant concentrations could decrease the gene expressions of deiodinases in adult rare minnow, and the expressions were tissuespecific.

In this study, the expressions of me were not significantly induced in the livers of adults (Fig. 2), whereas decreased in larvae and brains of females (Figs. 1 and 3). Moreover, the profiles in brains showed a positive correlation with plasma $\mathrm{T}_{4}$ levels in females. Previous studies have shown that hypothyroidism suppresses ME activities and expressions of their mRNA while restoring plasma $T_{3}$ increases them in males broiler chickens (Rosebrough et al., 2004). And enzyme activities and mRNA levels of malic enzyme were significantly up-regulated in the livers of rats by $\mathrm{T}_{3}$ (Dozin et al., 1985). These results may support that malic enzyme is a well-characterised endpoint of THs action (Rosebrough et al., 2006). In addition, previous studies have demonstrated that me gene show a pattern of tissue-specific expression, such as in herring tissues (Biegniewska et al., 1990), and in chick embryo fibroblasts (Chung and Goodridge, 1999). The present data suggested that exposure to acetochlor at environmentally relevant concentrations can decrease the gene expression of me in adult rare minnow, and the expressions are tissue-specific.

Our studies found that the expressions of nis were significantly decreased at the end of acetochlor exposure in larvae and brains of females (Figs. 1 and 3). In extrathyroidal tissues, the highest mRNA levels of nis was in the brains of rare minnow (data not shown). In deer mice, the highest nis expression level was in the stomach, followed by testes, brain, and large intestine, whereas very low expression of nis was observed in the lung, kidney, heart, and liver (Cheng et al., 2007). In human and rat, the nis was also expressed and active in extrathyroidal tissues, such as salivary glands, gastric mucosa, brain, glands, and kidney (Dohan et al., 2003). To our knowledge, no data are available to compare with the changes of nis mRNA levels in fish. In the thyroid gland of $X$. laevis tadpole, the thyroid-stimulating hormone (TSH) stimulates NIS activity via up-regulation of nis mRNA (Opitz et al., 2006). Perchlorate did not significantly increase nis gene expression in the kidney and stomach through drinking water for 28 days in deer mice (Cheng et al., 

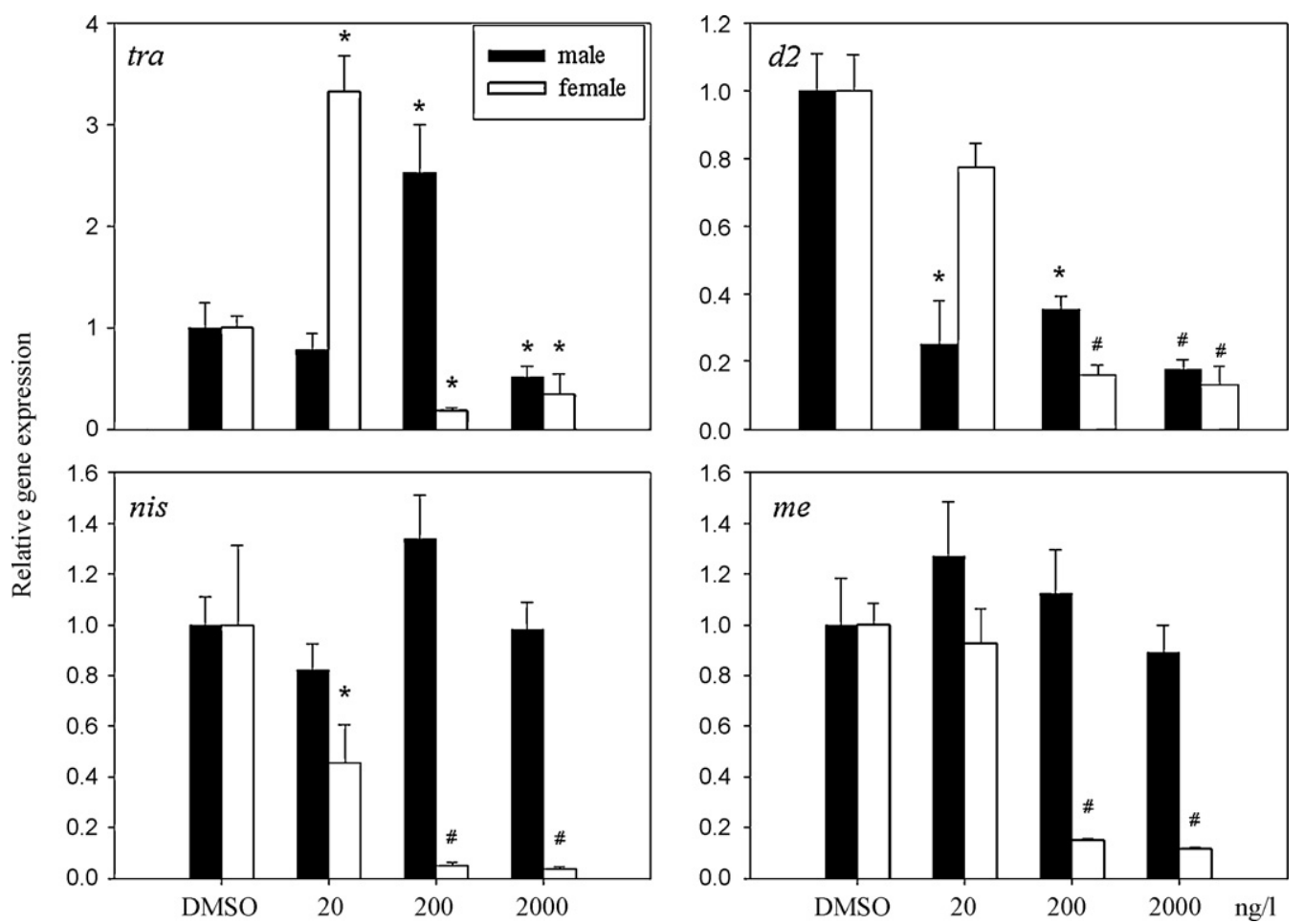

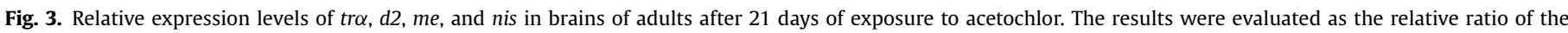
expression level of each mRNA to that of $\beta$-actin. Data expressed as mean \pm S.E. of each treatment (males or females, $n=5$ ). ${ }^{*} p<0.05$; ${ }^{*} p<0.01$, relative to control.

2007). Present data suggested that exposure to acetochlor could decrease the gene expressions of nis in brains of females.

In present study, the observation that down-regulation of THs related genes expression in larvae were found may indicate that normal development of larvae may be affected at environmentally relevant concentration of acetochlor. For adults, the effects of acetochlor treatment on mRNA expression were tissue-specific, and a significant down-regulation was detected only in the brains with little or no effect on the livers. The expression of these genes in females was more sensitive to acetochlor than those of males. Thyroid hormone is essential for brain development. Present data suggested that exposure to acetochlor may affect normal brain development.

In our study, the effects on thyroid function in rare minnow have been throughout investigated after 21 days of exposure to acetochlor. Most researches focused on the short-term exposure, such as 1-day exposure (Veldhoen and Helbing, 2001) and 6-day (Helbing et al., 2006) for $R$. catesbeiana tadpoles, 3-day (Crump et al., 2002) for X. laevis tadpoles, and 7-day (Cheek et al., 1999) for $R$. pipiens leopard frog eggs and tadpoles, respectively. Therefore, little is known about the effect on thyroid function in fish at environmentally relevant concentrations of acetochlor long-term exposure, and further studies are needed to examine this issue.

\section{Conclusion}

The gene expressions of THs related genes in larvae were sensitive to acetochlor. These results indicated that normal development of larvae might be affected at environmentally relevant concentrations of acetochlor. Exposure to acetochlor can decrease circulating $\mathrm{TH}$ levels of adults, and result in tissue-specific alternations of THs related genes expression in adults. The present data suggested that exposure to acetochlor may affect normal brain development, especially in females. However, further studies are needed to examine thyroid function and the effect of acetochlor on fish after long-term exposure.

\section{Acknowledgements}

This work was supported by Chinese Academy of Sciences (KZCX2-YW-Q02-05), National Basic Research Program of China (2009CB421605), and the National Natural Science Foundation of China (20737003, 20877089).

\section{References}

Arukwe, A., Jenssen, B.M., 2005. Differential organ expression patterns of thyroid hormone receptor isoform genes in p, $\mathrm{p}^{\prime}$-DDE-treated adult male common frog Rana temporaria. Environ. Toxicol. Pharmacol. 20, 485-492.

Barbash, J.E., Thelin, G.P., Kolpin, D.W., Gilliom, R.J., 2001. Major herbicides in ground water: results from the National Water-Quality Assessment. J. Environ. Qual. 30, 831-845.

Biegniewska, A., Skorkowski, E.F., Storey, K.B., 1990. Tissue specificity of the mitochondrial forms of malic enzyme in herring tissues. Comp. Biochem. Physiol. B Biochem. Mol. Biol. 95, 817-820.

Boyd, R.A., 2000. Herbicides and herbicide degradates in shallow groundwater and the Cedar River near a municipal well field, Cedar Rapids, Iowa. Sci. Total Environ. 248, 241-253.

Chao, L., Zhou, Q.X., Chen, S., Cui, S., Wang, M.E., 2007. Single and joint stress of acetochlor and $\mathrm{Pb}$ on three agricultural crops in northeast China. J. Environ. Sci. (China) 19, 719-724.

Charlier, C.J., Plomteux, G.J., 2002. Determination of organochlorine pesticide residues in the blood of healthy individuals. Clin. Chem. Lab. Med. 40, 361-364.

Cheek, A.O., Ide, C.F., Bollinger, J.E., Rider, C.V., McLachlan, J.A., 1999. Alteration of leopard frog (Rana pipiens) metamorphosis by the herbicide acetochlor. Arch. Environ. Contam. Toxicol. 37, 70-77.

Cheng, Q., Smith, E.E., Liu, F., Gentle, A., Hooper, M.J., Anderson, T.A., 2007. Effects of perchlorate on sodium-iodide symporter and pendrin gene expression in deer mice. Environ. Toxicol. 22, 390-398.

Chung, S.S., Goodridge, A.G., 1999. Cis-acting elements in the 5 '-flanking DNA of the malic enzyme gene regulate tissue-specific T3-responsiveness in chick embryo fibroblasts. Arch. Biochem. Biophys. 364, 1-12

Crane, H.M., Pickford, D.B., Hutchinson, T.H., Brown, J.A., 2004. Developmental changes of thyroid hormones in the fathead minnow, Pimephales promelas. Gen. Comp. Endocrinol. 139, 55-60. 
Crump, D., Werry, K., Veldhoen, N., Van Aggelen, G., Helbing, C.C., 2002. Exposure to the herbicide acetochlor alters thyroid hormone-dependent gene expression and metamorphosis in Xenopus laevis. Environ. Health Perspect. 110, 1199-1205.

Dohan, O., De la Vieja, A., Paroder, V., Riedel, C., Artani, M., Reed, M., Ginter, C.S., Carrasco, N., 2003. The sodium/iodide symporter(NIS): characterization, regulation, and medical significance. Endocr. Rev. 24, 48-77.

Dozin, B., Magnuson, M.A., Nikodem, V.M., 1985. Tissue-specific regulation of two functional malic enzyme mRNAs by triiodothyronine. Biochemistry 24 , 5581-5586.

Guo, Y., Meng, X.Z., Tang, H.L., Zeng, E.Y., 2008. Tissue distribution of organochlorine pesticides in fish collected from the Pearl River Delta, China: implications for fishery input source and bioaccumulation. Environ. Pollut. 155, 150-156.

Helbing, C.C., Ovaska, K., Ji, L., 2006. Evaluation of the effect of acetochlor on thyroid hormone receptor gene expression in the brain and behavior of Rana catesbeiana tadpoles. Aquat. Toxicol. 80, 42-51.

Hladik, M.L., Bouwer, E.J., Roberts, A.L., 2008. Neutral chloroacetamide herbicide degradates and related compounds in Midwestern United States drinking water sources. Sci. Total Environ. 390, 155-165.

Hogan, N.S., Crump, K.L., Duarte, P., Lean, D.R., Trudeau, V.L., 2007. Hormone crossregulation in the tadpole brain: developmental expression profiles and effect of T3 exposure on thyroid hormone- and estrogen-responsive genes in Rana pipiens. Gen. Comp. Endocrinol. 154, 5-15.

Hurley, P.M., 1998. Mode of carcinogenic action of pesticides inducing thyroid follicular cell tumors in rodents. Environ. Health Perspect. 106, 437-445.

Kolpin, D.W., Nations, B.K., Goolsby, D.A., Thurman, E.M., 1996. Acetochlor in the hydrologic system in the Midwestern United States, 1994. Environ. Sci. Technol. 30, 1459-1464.

Lengyel, Z., Foldenyi, R., 2003. Acetochlor as a soil pollutant. Environ. Sci. Pollut. Res. Int. 10, 13-18.

Marchand, O., Safi, R., Escriva, H., Van Rompaey, E., Prunet, P., Laudet, V., 2001. Molecular cloning and characterization of thyroid hormone receptors in teleost fish. J. Mol. Endocrinol. 26, 51-65.

Nie, A.Y., McMillian, M., Parker, J.B., Leone, A., Bryant, S., Yieh, L., Bittner, A., Nelson, J., Carmen, A., Wan, J., Lord, P.G., 2006. Predictive toxicogenomics approaches reveal underlying molecular mechanisms of nongenotoxic carcinogenicity. Mol. Carcinog. 45, 914-933.

Opitz, R., Trubiroha, A., Lorenz, C., Lutz, I., Hartmann, S., Blank, T., Braunbeck, T., Kloas, W., 2006. Expression of sodium-iodide symporter mRNA in the thyroid gland of Xenopus laevis tadpoles: developmental expression, effects of antithyroidal compounds, and regulation by TSH. J. Endocrinol. 190, 157-170.

Orozco, A., Valverde, R.C., 2005. Thyroid hormone deiodination in fish. Thyroid 15, 799-813.

Orozco, A., Villalobos, P., Valverde, R.C., 2002. Environmental salinity selectively modifies the outer-ring deiodinating activity of liver, kidney and gill in the rainbow trout. Comp. Biochem. Physiol. A Mol. Integr. Physiol. 131, 387-395.

Petrovic, M., Eljarrat, E., Lopez De Alda, M.J., Barcelo, D., 2004. Endocrine disrupting compounds and other emerging contaminants in the environment: a survey on new monitoring strategies and occurrence data. Anal. Bioanal. Chem. 378, 549-562.
Picard-Aitken, M., Fournier, H., Pariseau, R., Marcogliese, D.J., Cyr, D.G., 2007. Thyroid disruption in walleye (Sander vitreus) exposed to environmental contaminants: cloning and use of iodothyronine deiodinases as molecular biomarkers. Aquat. Toxicol. 83, 200-211.

Power, D.M., Llewellyn, L., Faustino, M., Nowell, M.A., Bjornsson, B.T., Einarsdottir, I.E., Canario, A.V., Sweeney, G.E., 2001. Thyroid hormones in growth and development of fish. Comp. Biochem. Physiol. C Toxicol. Pharmacol. 130, 447-459.

Reyns, G.E., Venken, K., Morreale de Escobar, G., Kuhn, E.R., Darras, V.M., 2003. Dynamics and regulation of intracellular thyroid hormone concentrations in embryonic chicken liver, kidney, brain, and blood. Gen. Comp. Endocrinol. 134, 80-87.

Rosebrough, R.W., Russell, B.A., McMurtry, J.P., 2006. Studies on doses of methimazole (MMI) and its administration regimen on broiler metabolism. Comp. Biochem. Physiol. A Mol. Integr. Physiol. 143, 35-41.

Rosebrough, R.W., Russell, B.A., Poch, S.M., Richards, M.P., 2004. Methimazole, thyroid hormone replacement, and lipogenic enzyme gene expression in broilers. Comp. Biochem. Physiol. C Toxicol. Pharmacol. 139, 189-194.

Scholz, S., Mayer, I., 2008. Molecular biomarkers of endocrine disruption in small model fish. Mol. Cell. Endocrinol. 293, 57-70.

U.S. EPA, 1994. Prevention, Pesticides and Toxic Substances. Questions and Answers, Conditional Registration of Acetochlor. U.S. EPA, Washington, DC, March 11, p. 18.

Van der Geyten, S., Byamungu, N., Reyns, G.E., Kuhn, E.R., Darras, V.M., 2005. Iodothyronine deiodinases and the control of plasma and tissue thyroid hormone levels in hyperthyroid tilapia (Oreochromis niloticus). J. Endocrinol. 184, 467-479.

van der Ven, L.T., van den Brandhof, E.J., Vos, J.H., Power, D.M., Wester, P.W., 2006. Effects of the antithyroid agent propylthiouracil in a partial life cycle assay with zebrafish. Environ. Sci. Technol. 40, 74-81.

Veldhoen, N., Helbing, C.C., 2001. Detection of environmental endocrine-disruptor effects on gene expression in live Rana catesbeiana tadpoles using a tail fin biopsy technique. Environ. Toxicol. Chem. 20, 2704-2708.

Wilson, A.G., Thake, D.C., Heydens, W.E., Brewster, D.W., Hotz, K.J., 1996. Mode of action of thyroid tumor formation in the male Long-Evans rat administered high doses of alachlor. Fundam. Appl. Toxicol. 33, 16-23.

Xue, N., Xu, X., Jin, Z., 2005. Screening 31 endocrine-disrupting pesticides in water and surface sediment samples from Beijing Guanting reservoir. Chemosphere 61, 1594-1606.

Ye, C., 2003. Environmental behavior of the herbicide acetochlor in soil. Bull. Environ. Contam. Toxicol. 71, 919-923.

Zha, J., Sun, L., Zhou, Y., Spear, P.A., Ma, M., Wang, Z., 2008. Assessment of 17alpha-ethinylestradiol effects and underlying mechanisms in a continuous, multigeneration exposure of the Chinese rare minnow (Gobiocypris rarus). Toxicol. Appl. Pharmacol. 226, 298-308.

Zha, J., Wang, Z., Wang, N., Ingersoll, C., 2007. Histological alternation and vitellogenin induction in adult rare minnow (Gobiocypris rarus) after exposure to ethynylestradiol and nonylphenol. Chemosphere 66, 488-495.

Zhang, X., Zha, J., Li, W., Yang, L., Wang, Z., 2008. Effects of 2, 4-dichlorophenol on the expression of vitellogenin and estrogen receptor genes and physiology impairments in Chinese rare minnow (Gobiocypris rarus). Environ. Toxicol. 23, 694-701. 